\title{
Geosciences
}

http://dx.doi.org/10.1590/0370-44672018720167

\footnotetext{
Flávia Cristina Silveira Braga ${ }^{1,2,6}$

https://orcid.org/0000-0002-5467-900X

Carlos Alberto Rosiere ${ }^{1,7}$

https://orcid.org/0000-0003-2364-6536

João Orestes Schneider Santos ${ }^{3,8}$

http://orcid.org/0000-0001-5524-7949

Steffen G. Hagemann ${ }^{4,9}$

https://orcid.org/0000-0003-0950-0864

Pedro Valle Salles ${ }^{2,5,10}$

https://orcid.org/0000-0002-4444-6958
}

${ }^{1}$ Universidade Federal de Minas Gerais - UFMG, Instituto de Geociências,

Belo Horizonte - Minas Gerais - Brasil.

${ }^{2}$ Universidade do Estado de Minas Gerais - UEMG, Faculdade de Engenharia,

João Monlevade - Minas Gerais - Brasil.

${ }^{3}$ Universidade do Estado do Amazonas - UEA

Manaus - Brasil.

${ }^{4}$ University of Western Australia, Centre for

Exploration Targeting, Perth - Australia.

${ }^{5}$ Centro Federal de Educação Tecnológica de Minas Gerais - CEFET-MG,

Belo Horizonte - Minas Gerais - Brasil.

E-mails: ${ }^{6}$ flaviacsbraga@gmail.com,

당siere@gmail.com, ${ }^{8}$ orestes.santos@bigpond.com 'steffen.hagemann@uwa.edu.au,

${ }^{10}$ pedrovallesalles025@gmail.com

\section{Depicting the 3D geometry of ore bodies using implicit lithological modeling: An example from the Horto- Baratinha iron deposit, Guanhães block, MG}

\begin{abstract}
The definition of geological domains is essential for mineral exploration and is traditionally done manually, section by section, in a laborious, time consuming and subjective process, to construct a 3D model. The technique referred to as implicit modeling is an option to model deposits in a fast and practical manner. This article presents the lithological model of the Horto-Baratinha iron deposit, located in the Antônio Dias municipality, central-eastern part of Minas Gerais state, constructed using the Leapfrog Geo ${ }^{\circledR}$ software. The deposit is situated at the Guanhães tectonic block that is a basement domain of the Neoproterozoic Araçuaí Orogenic Belt. The deposit is comprised of itabirite-hosted high-grade iron bodies ( $>60 \mathrm{wt} . \% \mathrm{Fe}$ ) associated with polydeformed mica schists, amphibole schist with a Statherian maximum deposition age, enclosed by Statherian granitoids of the Borrachudos Suite and crosscut by undeformed pegmatite dikes crystallized during Late Ediacaran-Cambrian. The sequence was affected by progressive multiple deformation phases, associated with the collisional stage of the Brasiliano Orogeny (630-560 Ma), generating a dome and basin mesoscale refolding shape. The model points the proximity between highgrade bodies and pegmatite indicating the possibility that the intrusions contribute to the iron mineralization.
\end{abstract}

Keywords: implicit lithological modeling, iron ore, Guanhães block. 


\section{Introduction}

The 3D geological modeling is considered a powerful tool to analyze and assess the structural framework of ore deposits. The construction of 3D models is usually done manually by linking digitalized 2D sections. In the last decade, various software started to work with the implicit modeling process, in which the geological attributes of a given rock mass is mathematically represented by a three-dimensional

\section{Geological setting}

The HBD is located in the Antônio Dias municipality, central-east part of Minas Gerais (Figure 1). Geologically, it is part of the Guanhães basement block, a major morphotectonic feature of the Neoproterozoic Araçuaí belt (Alkmim et al., 2006). The $250 \mathrm{~km}$ long and $140 \mathrm{~km}$ wide Guanhães block is made up of Archean gneisses, a large volume of Statherian granites of the anorogenic Borrachudos Suite, and tectonically dismembered supracrustal assemblages, which include function. Compared with the traditional method, the implicit modeling reduces user-based modeling bias by generating surfaces from lithological and structural data without manual digitization and linkage of sections or level plans (Cowan et al., 2003; Knight et al., 2007; Vollgger et al., 2015).

This article discusses the use of the implicit lithological modeling for ore deposit delineation. As an example, we modeled the 3D geometry of the HortoBaratinha iron ore deposit (HBD) located in the Guanhães tectonic block, near the southern end of the Espinhaço Range, Minas Gerais. Our goal is to demonstrate the application of implicit lithological modeling incorporating drill hole and surface mapping data. In addition, we compare our results with a model produced using exclusively drill hole data.

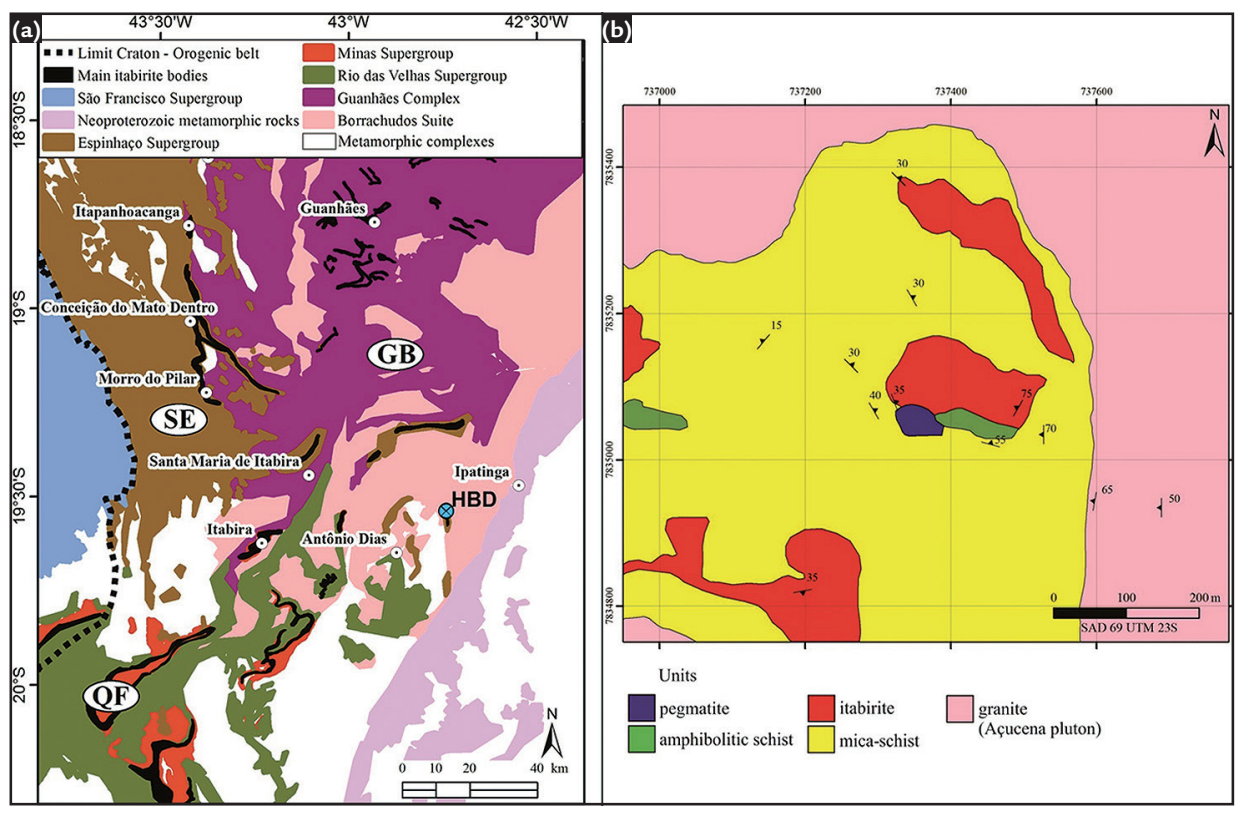

\subsection{Stratigraphy}

The rock types mapped and identified in drill holes in the HBD area (Figure

\subsubsection{Borrachudos Suite}

Granite is composed of quartz, microcline, plagioclase, biotite, muscovite, hornblende and opaque min-

\subsubsection{Mica schist}

Paraderived aluminous mica schists interlayered with quartzite layers are pres- 1b) were grouped into five informal units, which occur in the succession shown in

erals (magnetite and hematite). This rock presents a penetrative foliation defined mainly by biotite and is usu- schists, quartzites and itabirites (Silva, 2000; Silva et al., 2002; Alkmim et al., 2007; Noce et al., 2007; Brito Neves et al., 2014; Rosière et al., 2018). The HortoBaratinha orebody is hosted by one of these tectonic slices of metasedimentary rocks, specifically by itabirites (metamorphosed iron formation - IF) interlayered with metamorphic psammo-pelitic units (Silveira Braga et al., 2019).

According to regional geological maps, the IF-bearing sequence from HBD

is considered an inlier of Rio das Velhas Archean greenstone belt (Oliveira and Leite, 2000; Silva, 2000; Pinto and Silva, 2014). However, recent geochronological studies indicate that the sequence represents fragments of the Lower Espinhaço Supergroup (Serra de São José Group) and the IF is correlated with the Serra da Serpentina Group, defined by Rolim et al., (2016) at the Serpentina Range, deposited between the Orosirian and Statherian periods (Silveira Braga et al., 2019).

Figure 1

(a) Regional map of the Southern Espinhaço Range and Guanhães tectonic block, at the western border of the Neoproterozoic Araçuaí belt with the distribution of the main geological units and the location of Horto-Baratinha deposit (HBD). The distribution of the geological units is based and modified from Pinto and Silva (2014). Abbreviations: SE - Serra do Espinhaço fold-thrust belt block, GB- Guanhães block, QF - Quadrilátero Ferrífero Province. (b) Geological map of HBD (Silveira Braga et al., 2019).

Figure 2 and described below.

ally parallel to the foliation of the metasedimentary rocks.

ent at the top and bottom of the metasedimentary sequence. The main minerals are quartz, muscovite, biotite, sillimanite, garnet, tourmaline, kyanite, zoisite, cordi- 
erite, opaque minerals (mainly magnetite and hematite). The common accessory minerals are plagioclase, zircon, monazite, apatite, and titanite.
Figure 2

Simplified lithostratigraphic column of HBD (Silveira Braga et al., 2019).

\subsubsection{Amphibole schist}

It is stratigraphically located above the itabirite and below the top-micaceous schist. This unit has

\subsubsection{Itabirite}

Unit composed of itabirite (lowgrade ore $-\mathrm{Fe}<40 \%$ ) that hosts highgrade ore bodies ( $\mathrm{Fe}>60 \%$ ) discontinu-

\subsubsection{Pegmatite}

Centimetric to metric pegmatite dikes and sills crosscut the entire sequence. This is the only undeformed unit and is mainly composed of quartz, microcline, plagioclase, biotite, musco-

\subsection{Structures}

The Horto-Baratinha sequence was affected by progressive multiple deformation phases, associated with the collisional stage (630-560 Ma) of the Brasiliano Orogeny (Silveira Braga et al., 2018a; Silveira Braga et al., 2019). a scattered occurrence throughout the mapped area. The essential minerals are hornblende, tremolite-ac-

ously distributed inside it. The itabirite is mainly composed of quartz and lamellar hematite. The high-grade iron ore bodies

vite, and apatite. The intrusions have various sizes, from a few centimeters to 30 meters thick. Hydrothermal fluids associated with the pegmatite intrusions could be related to the Si leaching

The early development of shear zones parallel to the lithological contacts caused transposition and obliteration of all sedimentary structures and generation of the foliation planes in the axial plane position of isoclinal intrafolial tinolite, quartz, talc, cordierite and opaque minerals (lamellar and granular hematite, magnetite).

are metric to decametric, with a granoblastic fabric and mainly composed of granular hematite and magnetite.

from IF, crystallization of magnetite and granular hematite, and the consequent formation of high-grade iron bodies (Gomes et al., 2018; Silveira Braga et al., 2018b; Silveira Braga et al., 2019).

folds (Silveira Braga et al., 2019). The sequence has further undergone flexural folding with axes trending N-S and E-W, comprising a dome and basin mesoscale refolding shape (Silveira Braga et al., 2019). 


\section{3D lithological modeling}

The modeling process known as explicit relies on the manual definition of geological contacts and structures by digitization of $2 \mathrm{D}$ cross-sections that are later linked to generate 3D bodies and surfaces. The free hand design makes explicit modeling workflows time consuming and with a strong bias inherited from geological interpretation during crosssection drawing and linkage, resulting in unique and non-reproducible models. It must be viewed with caution to structural interpretation, due to its subjective and nonreproducible process (Cowan et al., 2003; Vollgger et al., 2015).

The implicit geological modeling process was introduced by Lajaunie et al., (1997) and it is based on data interpolation algorithms and firstly defines the continuous three-dimensional function, which describes the rock spatial distribution (Cowan et al., 2003; Knight et al., 2007; Rolo et al., 2017). The Radial Basis Function $(\mathrm{RBF})$ is used to interpolate the lithology and grade distribution (Cowan et al.,
2003). An implicit function (generic format $\mathrm{f}(\mathrm{x}, \mathrm{y}, \mathrm{z})=0$, where $\mathrm{x}, \mathrm{y}$, and $\mathrm{z}$ represent the coordinates) is computed and fitted to a set of spatial data such as lithological contact points along drill holes. A scalar value is assigned to every point in space. Isovalues are extracted and used to define 3D isosurface. This function is transformed into a surface, which may represent geological contact or a fault plane, and allows the extraction of the 3D object in an automatized way, eliminating the necessity of the section by section manual digitization. A surface of any resolution could be extracted from the implicit function, depending on computational limitations. Therefore, the implicit modeling of a solid is defined by the creation of a mathematical function that is modeled from the spatially interpolated drill hole data and/or surface data (structure attitude, contacts lines), and a solid surface is obtained by triangulation of this function (Cowan et al., 2003; Knight et al., 2007). Implicit modeling also permits the direct integration and processing of planar structural measurements, producing structural isosurfaces by adjusting the gradient of the scalar field (Hillier et al., 2013; Vollgger et al., 2015).

Compared with the explicit method, implicit modeling represents one to three orders of magnitude in time savings over manual digitization and allows a rapid update when including new drill hole data (Cowan et al., 2003; Knight et al., 2007; Boyle e Latscha, 2013). Another important advantage is the possibility of testing multiple hypotheses in a reasonable amount of time by applying structural trends calculated from structural measurements, adapting boundaries, and so forth (Jessell, 2001).

The isosurfaces will always try to achieve a smooth fit due to the nature of the RBF-based spatial interpolation. Additional data may be manually introduced based on geological knowledge and experience to generate a model that complies better with the understanding at the time of creation (Vollgger et al., 2015).

\section{3D implicit lithological modeling of the Horto-Baratinha iron ore deposit}

In our study, we aimed to construct the 3D lithological model of HBD, based on available drill hole lithological data, surface mapping and structural data collected in the field. Two different models were generated: one using only drill hole data and another combining this data with surface geological information. The surface mapping was conducted along the pits and around it, with description of 223 waypoints. The 3D lithological model aims to only resolve large-scale (decametric-scale) units shapes meaning that smaller-scale shapes, such as parasitic folds are not represented.

The Leapfrog $\mathrm{Geo}^{\circledR}$ implicit modeling software package (Cowan et al., 2002) uses different types of Contact Surfaces, which are planes that represent the geological contacts and generate the three-dimensional representation of the lithological units. The system employs $\mathrm{RBF}$ to spatially interpolate large drill hole datasets in order to build a 3D geological model. The 3D models produced were extracted using 72 drill hole $(5,672 \mathrm{~m})$ database provided by Bemisa Company in 2015, including lithological data (drill hole logs), collar and survey data, and the digital elevation model (DEM). The data validation and compost- ing were done using Leapfrog.

The different types of Contact Surfaces result in different shapes and cut older geologic units in different ways. The software provides four types of Contact Surface planes, as described by ARANZ Geo Limited (2016):

- Deposit: It is sheet-like and does not cut older volumes, so it appears conformably on top of older volumes.

- Erosion: It is analogous to the Deposit Contact Surface; however, it cuts away other Contact Surfaces present on the older side of the Erosion Contact Surface.

- Intrusion: It has a rounded shape, with the interior of the plane representing the intrusion lithology. This Contact Surface characteristically removes older Contact Surfaces and replaces them with the intrusive lithology.

- Vein: This Contact Surface eliminates the previous surfaces along its domain, and its boundaries are defined by hangingwall and footwall surfaces.

The choice of the surface and the relative chronological order should be determined by the geologist to control the spatial extension of the lithological volume. To generate the lithological wireframe model, it is necessary to: (1) define the type of Contact Surface of each lithology; (2) refine the Contact Surfaces according to the characteristics of the lithology, and (3) arrange them in chronological order. Then the software will use the surfaces and the chronological order to discriminate the 3D geological model into units (ARANZ Geo Limited, 2016). The refining process of the Contact Surface may be done by adding information such as the orientation of contacts, lines representing surface contacts, surface points, lines representing the attitude of the structures, structural trends and so forth.

As described by ARANZ Geo Limited (2016) the Contact Surface should not be chosen based only on its geological origin, but it is important to consider the shape and cutting behavior of each one. The users should choose the Contact Surface for each lithostratigraphic unit based on the geological characteristics observed in the field and drill holes and then choose which Contact Surface available in the software better adapts to each situation.

The five main geological units that make up the host rocks of HBD (Section 2.1) were used to generate the $3 \mathrm{D}$ lithological model. The general surface resolution used to de model was $10 \mathrm{~m}$, which is 
adaptive for each unit and defines the size of the triangles used to create a surface.

The units of HBD were modeled as the following Contact Surfaces, from the youngest to the oldest:

- Pegmatite (PEG) - Intrusion;

- Amphibole schist unit (XIF) Intrusion;

- Itabirite and high-grade iron ore (ITA) - Vein;

- Mica schist unit (XIS) - Deposit (background);

- Granite (GNA) - Intrusion.

All the Contact Surfaces were created based on drill hole data and refined with the support of additional information: lines representing mapped surface contacts (Figure 3a); dip and dip direction of the contacts at the surface (Figure 3a); and the dip direction lines (Figure 3b). The dip direction lines represent a structural trend and were drawn from surface to subsurface in specified areas according to structural trends observed during the surface mapping (Figure 3b) based on the main structural measurements (Figure 3a).

The surface resolution was adapted to $5 \mathrm{~m}$ for the less extensive units XIF and PEG. The PEG, GNA, and XIS were modeled using a 1:1:1 ellipsoidal ratio that is the default option. The surface contact line of PEG (Figure 3a) was used as an input in the Contact Surface.

The amphibole schist unit was modeled as an Intrusion, due to its scattered occurrence but concordant with the other metasedimentary units, applying the same layer orientation. This was possible using the XIF dip direction lines and the surface contact as inputs in the Contact Surface (Figure 3), as well as a structural trend created based on the GNA surface.

The ITA was modeled as a Vein because this Contact Surface best adapted to the shape observed in the field. Lines representing the ITA footwall and hangingwall dip directions were also applied as inputs in the Contact Surface (Figure $3 \mathrm{~b})$. To check the position of high-grade bodies inside the ITA unit and its relation with pegmatite, these intervals were posteriorly modeled as an Intrusion, using 1:1:1 ellipsoidal ratio and $5 \mathrm{~m}$ of resolution.

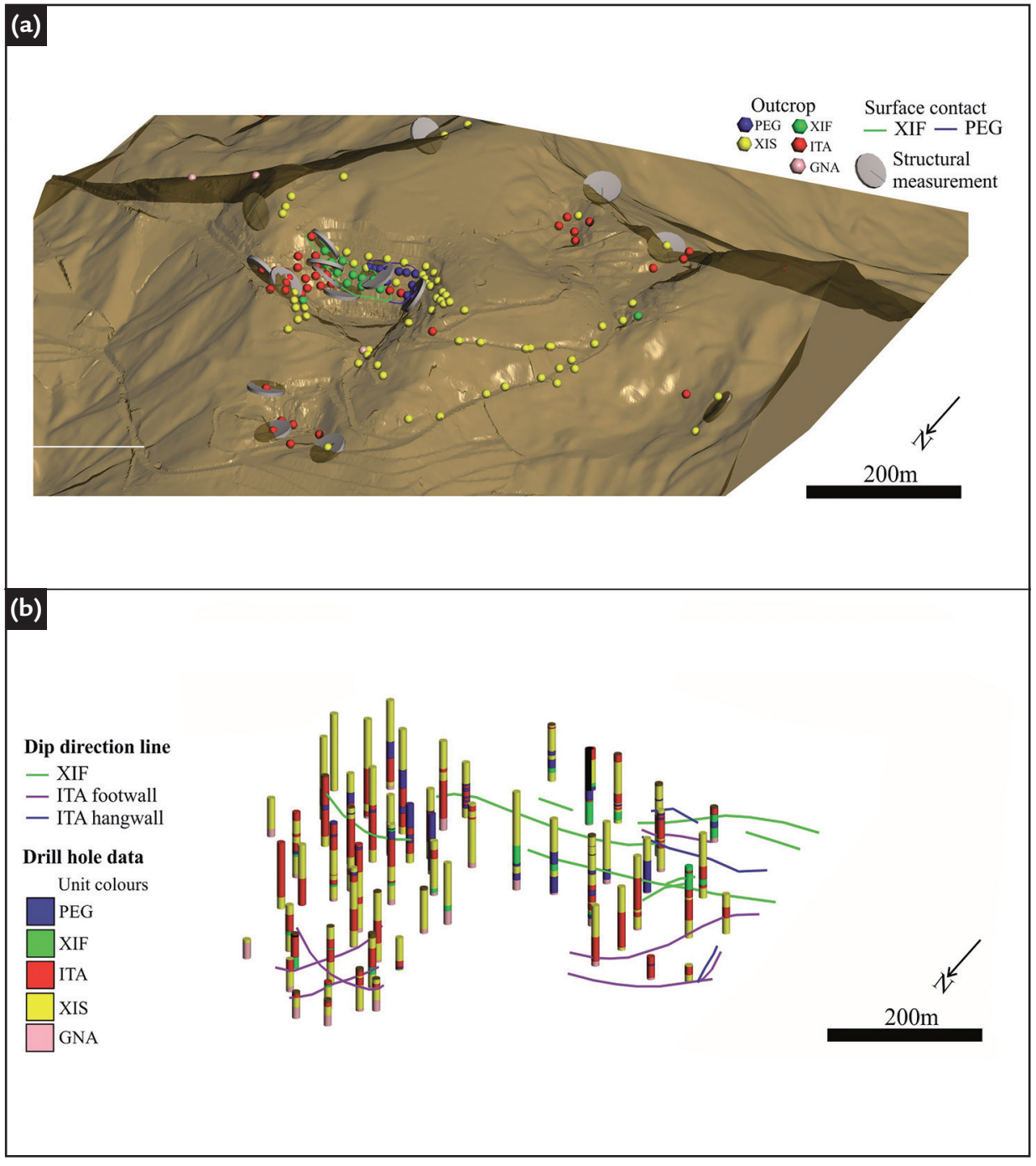

Data used to create the lithological 3D model of HBD in Leapfrog Geo ${ }^{\circledR}$. (a) Surface data: DEM, outcrops lithology, main structural measurements of the lithological contact, XIF and PEG surface contact lines. (b) Subsurface data: drill hole lithology and dip direction lines.

\section{Results and discussions}

Figure 4 shows the lithological 3D model created. Every Contact Surface generated agrees with the position and attitude observed in the field. This was only possible due to the information used to refine the Contact Surface (dip

direction and surface contacts lines added as inputs in the Contact Surfaces) and the use of the Contact Surfaces that best adapted to the shape of the layers. Figure 5 shows the lithological 3D model created using only drill hole data and the Deposit Contact Surface for all metasedimentary units. It is possible to see that most of the outcrops are not in agreement with the lithological model of Figure 5, but they best-fit with the model of Figure 4. 

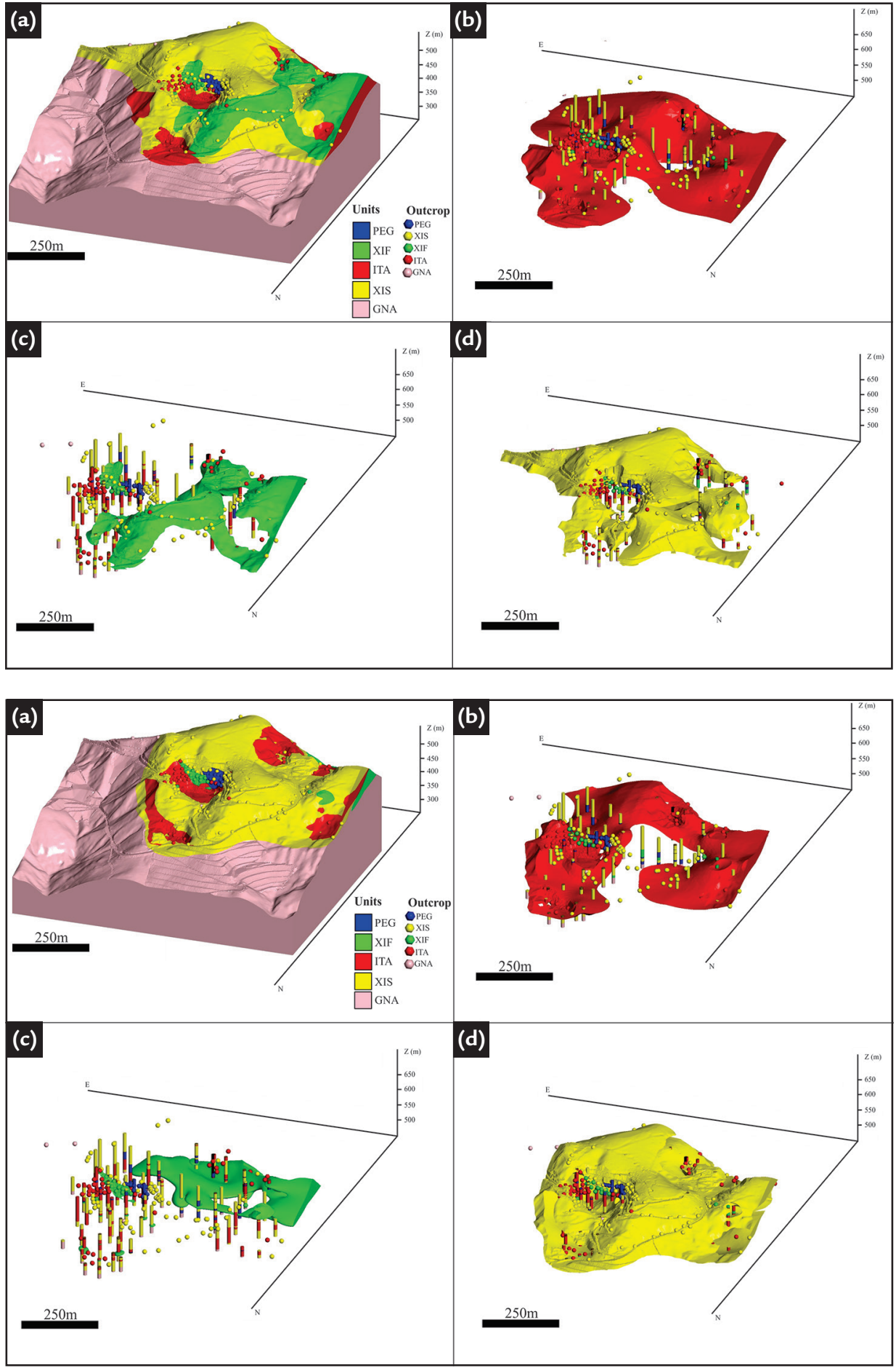

As demonstrated by Basson et al. (2018), although most lithologies of the deposit are sedimentary in origin, Leapfrog $\mathrm{Geo}^{\circledR}$ creates the models according to their geometry. In order to obtain realistic shapes in the present article, we adopted the Deposit Contact Surface for the more extensive metasedimentary lithology (XIS), and the discontinuous layers were modeled as Intrusion or Vein. To keep the structural trend of these less extensive layers in agreement with the other units, dip direction lines (Figure $3 \mathrm{~b}$ ) and structural trends were applied that made possible the modeling of XIF and ITA in agreement with the outcrop observation.

When modeled using the Deposit Contact Surface, the ITA and XIF units behaved as continuous layers throughout the area (Figure 5), in disagreement with the geological surface map (Figure 1b).

Both models, the adapted (Figure 4 ) and the generic (Figure 5), present the same mesoscopic layer shapes, which look like the dome and basin refolding shape proposed by Silveira Braga et al. (2019) for HBD. The authors compare the structural non-cylindrical refold
Figure 4

Lithological Horto-Baratinha 3D model created in Leapfrog Geo ${ }^{\circledR}$ based on surface and subsurface data. (a) Completed 3D lithological model. (b) Lithological model of ITA unit, modeled using Vein Contact Surface. (c) Lithological model of XIF unit, modeled as an Intrusion. (d) Lithological model of XIS unit, modeled as a Deposit.

Figure 5

Lithological Horto-Baratinha 3D model created in Leapfrog $\mathrm{Geo}^{\circledR}$ based only in DEM and drill hole data. (a) Completed 3D lithological model. (b) Lithological model of ITA unit, modeled using Deposit Contact Surface. (c) Lithological model of XIF unit, modeled as a Deposit. (d) Lithological model of XIS unit, modeled as a Deposit.

pattern of HBD with the experimental soft model obtained by Ghosh et al. (1993) in a superposed buckling experiment. Even though the generic model is not totally in agreement with the surface mapping, it provides a coherent general geometry of the units.

The high-grade iron ore intervals were modeled based on the drill hole description to verify its relationship with the pegmatite intrusions. Figure 6 shows that the more extensive and continuous high-grade ore bodies are close to the biggest pegmatite intrusions. 
Figure 6

Map showing the distribution of the pegmatite intrusions and high-grade bodies at left and sections with the distribution of all units modeled at right.

\section{Conclusion}

The Leapfrog Geo ${ }^{\circledR}$ software generated a lithological 3D model by implicit modeling, which is in agreement with the shape and orientation (strike and dip) of the rock units obtained from surface mapping (Figure 1b) and the dome and basin refolding shape interpreted by Silveira Braga et al., (2019). The delivered highgrade ore 3D model (Figure 6), points to a close spatial relationship with the pegmatite bodies, supporting the influence of the magmatic-hydrothermal fluids in the iron mineralization. The inclusion of parameters such as lines representing the contact at the surface and the general

\section{Acknowledgments}

The authors would like to express their gratitude to BEMISA and its team for supplying drill hole data and supporting the field work in Horto-Baratinha mine; ARANZ Geo Limited - Owners of Leapfrog, QG Consulting and the geologist Marcelo

\section{References}

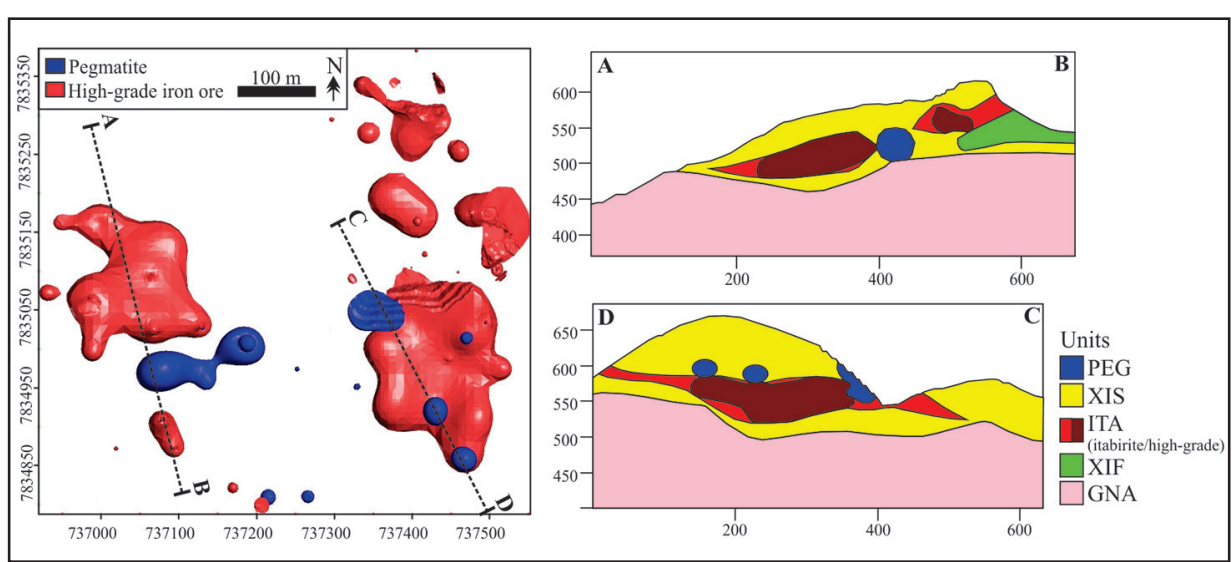

structural trend of the layers (Figure 3) helped to refine the outcrop pattern. Another important characteristic of the implicit modeling observed in this study case is the importance of the definition of Contact Surface based on its intersection behavior but not necessarily on the geological origin, in order to provide best fitted 3D units according to field observations.

The implicit modeling is accurate, flexible and efficient when compared with the explicit methodology, as pointed by Knight et al., (2007). In data-rich environments, the high-data density allows direct computation of bound- aries and surfaces without manual, knowledge-driven digitization (Vollgger et al., 2015). The implicit modeling was herein used as a semi-automatic tool since we needed to refine the modeling parameters according to the local geological characteristics. This refining was necessary mainly due to the open and irregular drill hole data throughout the modeled area. However, in the present case, the analyses of medium to low drill hole data density turned out to be sufficiently accurate in the interpretation of a non-cylindrical deposit scale geometry using Leapfrog $\mathrm{Geo}^{\circledR}$ default workflow.
Freitas by the permission and support to the usage of Leapfrog $\mathrm{Geo}^{\circledR}$. We also thank the anonymous reviewers for constructive criticism and Jório Coelho for editorial handling. This study was financed by the Coordenação de Aperfeiçoamento de Pessoal de Nível
Superior - Brasil (CAPES) - Finance Code 001 (scholarship / Programa de Doutorado Sanduíche no Exterior / Pr. n $\left.{ }^{\circ} 88881.134959 / 2016-01\right)$ and Fundação de Amparo à Pesquisa de Minas Gerais (FAPEMIG/CRA-APQ 01178-15).

AlKMiM, F. F., PEDrOSA-SOARES, A. C., PERES, G. G., CRUZ, S. C. P., WHITTINGTON, A. Kinematic evolution of the Araçuai-West Congo orogen in Brazil and Africa: Nutcracker tectonics during the Neoproterozoic assembly of Gondwana. Precambrian Research, v. 149, n. 1-2, p. 43-64, 2006.

ALKMIM, F. F., PEDROSA-SOARES, A. C., NOCE, C. M., CRUZ, S. C. P. Sobre a evolução tectônica do Orógeno Araçuaí-Congo Ocidental. Geonomos, v. 15, n. 1, p. 25-43, 2007.

ARANZ GEO LIMITED. LEAPFROG GEO 4.0 HELP. Available in: <http://help. leapfrog3d.com/Geo/4.0/en-GB/Content/intro.htm>. Accessed out-2017.

BASSON, I. J., THOMAS, S. A. J., STOCH, B., ANTHONISSEN, C. J., MCCALL, M. J., BRITZ, J., MACGREGOR, S., VILJOEN, S., NEL, D., VIETZE, M., STANDER, C., HORN, J., BEZUIDENHOUT, J., SEKOERE, T., GOUS, C., BOUCHER, H. The structural setting of mineralisation at Kolomela Mine, Northern Cape, South Africa, based on fully-constrained, implicit 3D modeling. Ore Geology Reviews, v. 95, n. April, p. 306-324, 2018.

BOYLE, C., LATSCHA, A-A. Implicit geological modelling of iron ore deposits. In: Proceedings Iron Ore 2013. Annals... Perth: The Australasian Institute of Mining 
and Metallurgy, 2013, v. 1, p. 57-66.

BRITO NEVES, B. B., FUCK, R. A., PIMENTEL, M. M. The Brasiliano collage in South America: a review. Brazilian Journal of Geology, v. 44, n. 3, p. 493-518, 2014.

COWAN, E. J., BEATSON, R. K., FRIGHT, W. R., MCLENNAN, T. J., MITCHELL, T. J. Rapid geological modeling. In: APPLIED STRUCTURAL GEOLOGY FOR MINERAL EXPLORATION AND MINING, INTERNATIONAL SYMPOSIUM. Kalgoorlie, 2002, September, p. 23-25.

COWAN, E. J., BEATSON, R. K., ROSS, H. J., FRIGHT, W. R., MCLENNAN, T. J., EVANS, T. R., CARR, J. C., LANE, R. G., BRIGHT, D. V., GILLMAN, A. J., OSHUST, P. A., TITLEY, M. Practical implicit geological modeling. In: INTERNACIONAL MINING GEOLOGY CONFERENCE, 5. Annals... Bendigo: The Australasian Institute of Mining and Metallurgy, 2003, v. 8, p. 89-99.

GHOSH, S. K., MANDAL, N., SENGUPTA, S., DEB, S. K., KHAN, D. Superposed buckling in multilayers. Journal of Structural Geology, v. 15, n. 1, p. 95-111, 1993.

GOMES, S. D., BERGER, S., FIGUEIREDO E SILVA, R. C., HAGEMANN, S. G., ROSIÈRE, C. A., BANKS, D. A., LOBATO, L. M. Oxide chemistry and fluid inclusion constraints on the formation of itabirite-hosted iron ore deposits and associated pegmatites at the eastern border of the Southern Espinhaço Range, Brazil. Ore Geology Reviews, v. 95, n. March, p. 821-848, 2018.

HILLIER, M., DEKEMP, E. A., SCHETSELAAR, E. 3D form line construction by structural field interpolation (SFI) of geologic strike and dip observations. Journal of Structural Geology, v. 51, p. 167-179, 2013.

JESSELL, M. Three-dimensional geological modeling of potential-field data. Computers \& Geosciences, v. 27, p. 455-465, 2001.

KNIGHT, R. H., LANE, R. G., ROSS, H. J., ABRAHAM, A. P. G., COWAN, J. Implicit ore delineation. In: FIFTH DECENNIAL MINERAL EXPLORATION CONFERENCE ON MINERAL EXPLORATION, 5, 2007. Toronto. Annals... Toronto: Mine Site Exploration and Ore Delineation \& Ore Deposits and Exploration Technology, 2007, v. 1, p. 1165-1169.

LAJAUNIE, C., COURRIOUX, G., MANUEL, L. Foliation fields and 3D cartography in Geology: principles of a method based on potential interpolation. Mathematical Geology, v. 29, n. 4, p. 571-584, 1997.

NOCE, C. M., PEDROSA-SOARES, A. C., SILVA, L. C., ALKMIM, F. F. O embasamento arqueano e paleoproterozóico do Orógeno Araçuaí. Geonomos, v. 15, n. 1, p. 17-23, 2007.

OlIVEIRA, A. A. K., LEITE, C. A. S. Projeto Leste: Folha Ipatinga - SE.23-Z-D-II, escala 1:100.000. Belo Horizonte: SEME/COMIG/CPRM, 2000, 58 p. (Volume 20).

PINTO, C. P., SILVA, M. A. da. Mapa geológico do estado de Minas Gerais, escala 1:1.000.000. Belo Horizonte: CPRM/CODEMIG, 2014.

ROLIM, V. K., ROSIÈRE, C. A., SANTOS, J. O. S., MCNAUGHTON, N. J. The Orosirian-Statherian banded iron formation-bearing sequences of the southern border of the Espinhaço Range, Southeast Brazil. Journal of South American Earth Sciences, v. 65, p. 43-66, 2016.

ROLO, R. M., RADTKE, R., COSTA, J. F. C. L. Signed distance function implicit geologic modeling. REM - International Engineering Journal, v. 70, n. 2, p. 221-229, 2017.

ROSIÈRE, C. A., HEIMANN, A., OYHANTÇABAL, P., SANTOS, J. S. O. The Iron Formations of the South American Platform. In: SIEGESMUN, S. et al. (Eds.). Geology of Southwest Gondwana. 2018, cap. 18, p. 493-521.

SILVA, S. L. DA. Projeto leste: Folha Coronel Fabriciano - SE.23-Z-D-V, escala 1:100.000. Belo Horizonte: SEME/COMIG/CPRM, 2000. 71 p. (Volume 24).

SILVA, L. C., ARMSTRONG, R., NOCE, C. M., CARNEIRO, M. A., PIMENTEL, M. M., PEDROSA-SOARES, A. C., LEITE, C. A., VIEIRA, V. S., SILVA, M. A., PAES, V. J. C., CARDOSO-FILHO, J. M. Reavaliação da evolução geológica em terrenos pré-cambrianos brasileiros com base em novos dados U-Pb SHRIMP, parte II: Orógeno Araçuaí, Cinturão Mineiro e Cráton São Francisco Meridional. Revista Brasileira de Geociências, v. 32, p. 513-528, 2002.

SILVEIRA BRAGA, F. C., ROSIÈRE, C. A., SANTOS, J. O. S., HAGEMANN, S. G., SALLES, P. V. The Horto-Baratinha itabirite-hosted iron ore: a basal frag- 
ment of the Espinhaço Basin in the eastern São Francisco Craton. Journal of South America Earth Science, v. 90, p. 12-33, 2019.

SILVEIRA BRAGA, F. C., ROSIËRE, C. A., SANTOS, J. O. S., HAGEMANN, S. G., SALLES, P. V. Análise estrutural de região polideformada baseado em autovetores e modelamento implícito: estudo de caso do depósito de ferro de Horto-Baratinha, leste do Cráton do São Francisco, Brasil. In: CONGRESSO BRASILEIRO DE GEOLOGIA, 49. Annals... Rio de Janeiro: Sociedade Brasileira de Geologia, 2018a, v. 1, p. 1410.

SILVEIRA BRAGA, F. C., ROSIÈRE, C. A., SANTOS, J. O. S., HAGEMANN, S. G., SALLES, P. V. Mineralização de ferro dos depósitos Horto-Baratinha e Cuité, leste do Cráton São Francisco, Brasil. In: CONGRESSO BRASILEIRO DE GEOLOGIA, 49. Annals... Rio de Janeiro: Sociedade Brasileira de Geologia, 2018b, v. 1, p. 709.

VOLLGGER, S. A., CRUDEN, A. R., AILLERS, L., COWAN, E. J. Regional dome evolution and its control on ore-grade distribution: Insights from 3D implicit modeling of the Navachab gold deposit, Namibia. Ore Geology Reviews, v. 69, p. 268-284, 2015.

Received: 12 November 2018 - Accepted: 7 March 2019. 